\title{
Kajian Bioinformatika Penghambatan Alosterik Asemanan Dan Glukomanan Terhadap C-JUN NH2 Terminal Kinase (JNK)
}

\section{Dewi Ratih Tirto Sari ${ }^{1 *}$, Reni Ustiatik ${ }^{2}$, Jatmiko Eko Witoyo ${ }^{3}$, Gabriella Chandrakirana Krisnamurti $^{4}$, Yohanes Bare ${ }^{5}$}

${ }^{1}$ Pusat Studi SMONAGENES, Universitas Brawijaya, Malang, Indonesia, 65145

${ }^{2}$ Program Doktor Ilmu Pertanian, Pascasarjana Pertanian, Universitas Brawijaya, Malang, Indonesia, 65145

${ }^{3}$ Jurusan Teknologi Industri Pertanian, Fakultas Teknologi Pertanian, Universitas Brawijaya, Malang, Indonesia, 65145

${ }^{4}$ Biotechnology Program, School of Bioresources and Technology, King Mongkut's University of

Technology Thonburi, 10150 Bang Khun Thian, Bangkok, Thailand

${ }^{5}$ Program Studi Pendidikan Biologi, Fakultas Keguruan dan Ilmu Pendidikan, Universitas

Nusa Nipa, Jl Kesehatan No 03, Maumere, Indonesia

Email": dratih303@gmail.com

\section{ABSTRAK}

cJun NH2 terminal Kinase (JNK) merupakan protein kinase family MAPK yang berperan dalam $j$ alur pensinyalan penyakit metabolisme, salah satunya dalam regulasi faktor resiko obesitas. Penelitian in bertujuan untuk mengeksplorasi potensi asemanan dan glukomanan dalam menghambat JNK sebagai antidiabetes.metode pendekatan molecular docking digunakan untuk mengidentifikasi interaksi antara senyawa asemanan dan glukomanan terhadap protein JNK. Asemanan dan glukomanan berikatan di sisi aktif yang berbeda satu sama lain. Residu sisi aktif asemanan berada di close gate protein JNK, sedangkan glukomanan menunjukkan sisi aktif jalur ikatan inhibitor dari JNK. Asemanan dan glukomanan menghambat aktivitas JNK dengan berikatan di sisi non-katalitik dan diprediksi penghambatan protein JNK oleh kedua senyawa secara alosterik yang dapat merubah konformasi protein JNK. Selain itu, asemanan berikatan dengan kuat terhadap protein JNK dengan jenis ikatan hydrogen, interaksi hidrofobik dan elektrostatik dengan energi ikatan yang lebih rendah dari glukomanan - JNK. Penelitian disimpulkan bahwa senyawa asemanan dan glukomanan berpotensi sebagai antiobesitas dengan peranannya sebagai inhibitor terhadap protein JNK.

Kata Kunci: Alosterik, Asemanan, Glukomanan, protein JNK 


\section{PENDAHULUAN}

Obesitas merupakan salah satu kasus yang banyak ditemui di negara berkembang seperti Indonesia. Obesitas didefinisikan sebagai kondisi berlebihnya berat badan yang diakibatkan oleh menumpuknya lemak (Bakker \& Nieuwdorp, 2014; Makki dkk., 2013; Nabavi dkk., 2015). Salah satu faktor yang menyebabkan obesitas yaitu gaya hidup, konsumsi makanan yang tidak seimbang dan kurangnya aktivitas olahraga memicu akumulasi lemak pada tubuh (Xie dkk., 2018). Faktor resiko obesitas beragam, diantaranya menstimulasi berbagai penyakit metabolik seperti diabetes mellitus type 2, penyakit jantung, hipertensi, dan resiko terinfeksi virus seperti influenza dan COVID-19 (González-castejón \& Rodriguez-casado, 2011; Mojiminiyi dkk., 2007; Raipuria, Hardy, Bahari, \& Morris, 2015). Berbagai strategi dikembangkan untuk menurunkan angka obesitas, diantaranya dengan mengatur pola makan (diet), olahraga dan gaya hidup sehat. Jenis makanan yang banyak direkomendasikan untuk mengurangi obesitas dan resikonya yaitu dengan konsumsi suplemen makanan yang kaya akan serat (Hirata dkk., 2011; Mohamed dkk., 2014; Nabavi dkk., 2015; Patra \& Nithya, 2015).

Suplemen makanan yang dapat dikonsumsi untuk menurunkan obesitas yaitu $\beta$-glukan, chitosan, the hijau, glukomanan, gelatin/agar dan lainnya. $\beta$-glukan dilaporkan memiliki efek antiobesitas dengan menurunkan laju absorbsi karbohidrat dan lipid. Selain itu, $\beta$-glukan juga mampu menurunkan massa tubuh. Chitosan juga dilaporkan sebagai antiobesitas. Chitosan merupakan polisakarida yang berikatan dengan glukosamina dan diturunkan dari proses deasetilasi kitin. Chitosan memiliki kadar lemak yang rendah, sehingga mampu berperan mengurangi resiko obesitas (Chang dkk., 2013; Ciecierska dkk., 2019). Chitosan juga menurunkan peroksidase lipid dengan peranannya sebagai antioksidan eksogen. Suplemen makanan untuk diet lainnya yaitu glukomanan dan asemanan (Chang dkk.., 2013). Glukomanan banyak ditemukan di umbi porang, sedangkan asemanan banyak ditemukan pada tanaman lidah buaya (Aloevera). Glukomanan dilaporkan sebagai antiobesitas dengan menurunkan kadar kolesterol total, LDL, dan berat badan secara signifikan. Sementara ekstrak aloevera mampu menurunkan persentase lemak tubuh dan berat lemak (Devaraj dkk., 2019; Yazdi, 2019). Potensi antiobesitas baik glukomanan maupun asemanan telah banyak dilaporkan dari data in vivo, namun mekanisme antiobesitas pada kedua senyawa masih diteliti.

Salah satu target antiobesitas yaitu protein cJun NH2 terminal kinase (JNK). Protein JNK merupakan protein kinase kelompok famili protein MAP-kinase (MAPK) untuk fosforilasi. 
Protein JNK berperan dalam berbagai mekanisme terutama dalam pensinyalan penyakit metabolisme, seperti diabetes mellitus tipe 2, obesitas, artherosklerosis, arthritis, dan penyakit kardiovaskuler (Bardwell dkk., 2009; Duong dkk., 2020; Kragelj dkk., 2015). Penelitian ini bertujuan untuk mengeksplorasi potensi senyawa asemanan dan glukomanan sebagai anti-obesitas melalui penghambatan protein JNK secara in silico.

\section{METODOLOGI PENELITIAN}

Penelitian menggunakan pendekatan kajian bioinformatika dengan data sekunder. Senyawa asemannan (CID 72041) dan glucomannan (CID 24892726) diunduh struktur tiga dimensinya dari database PubChem. Struktur 3D protein JNK diunduh dari database protein data bank (PDB) dengan ID 2p33 (Alam dkk., 2007). Protein JNK dipreparasi dengan memprediksi daerah sisi aktif (Cavity) protein dan didocking dengan senyawa asemanan dan glukomanan dengan software Molegro Virtual Docker 5 (Bitencourt-Ferreira \& de Azevedo, 2019). Interaksi asemanan, glukomanan dengan protein JNK divisualisasi dengan tampilan 3D dengan perangkat lunak Discovery Studio v.21.1.1 dan analisis 2D dengan Molegro Virtual Docker 5 (BitencourtFerreira \& de Azevedo, 2019).

\section{HASIL DAN PEMBAHASAN}

Asemanan berikatan dengan protein cJun NH2 terminal Kinase dengan ikatan elektrostatik pada residu A:LYS68. Ikatan hidrogen mendominasi interaksi asemanan dengan protein JNK yaitu pada residu GLU160, GLN155, GLN158 dan PRO69 (Gambar 1). Menariknya GLN158 teridentifikasi diikat oleh asemanan dengan jarak ikatan dengan atom yang bervariasi, yaitu 1,8; 1,$8 ; 1,9 ; 1,4$; dan 2,6 A dengan ikatan hidrogen. Asemanan juga memiki sisi aktif terhadap JNK pada MET159 dan LEU161 dengan interaksi hidrofobik dengan jarak ikatan masing-masing 4,3 A dan 4,5 A (Tabel 1). Glukomanan menunjukkan sisi aktif terhadap protein JNK yang berbeda dari Asemanan. Sisi aktif glukomanan terhadap protein JNK yaitu ALA74, SER217, ASN194, ARG107, THR103, GLN102, dan LYS191 (Gambar 1). Glukomanan mengikat residu ALA74 pada gugus NH dengan jarak ikatan 1,7A, SER217 juga berinteraksi dengan JNK dengan interaksi hidrogen dengan jarak 2,6 A. selain itu SER217 menunjukkan beberapa interaksi dengan dengan protein JNK dengan jarak 2,7; 2,6; 2,1; dan 1,9A (Tabel 1). Interaksi residu SER217 dibeberapa temapat mengindikasikan glukomanan memiliki kecenderungan mengikat dibeberapa domain 
tersebut. Selain residu SER217, glukomanan juga menunjukkan dominasi residu yang diikat yaitu ASN194 yang berikatan dengan interaksi hidrogen, dan unfavorable. Residu asam amino SER217 protein JNK juga teridentifikasi merupakan sisi aktif senyawa 6-gingerol jahe dengan ikatan hidrofobik (Bare dkk., 2019). Residu ALA74 yang merupakan sisi aktif glukomanan - JNK juga teridentifikasi pada 8-shogaol (Bare dkk., 2020).

\section{Asemanan - JNK}
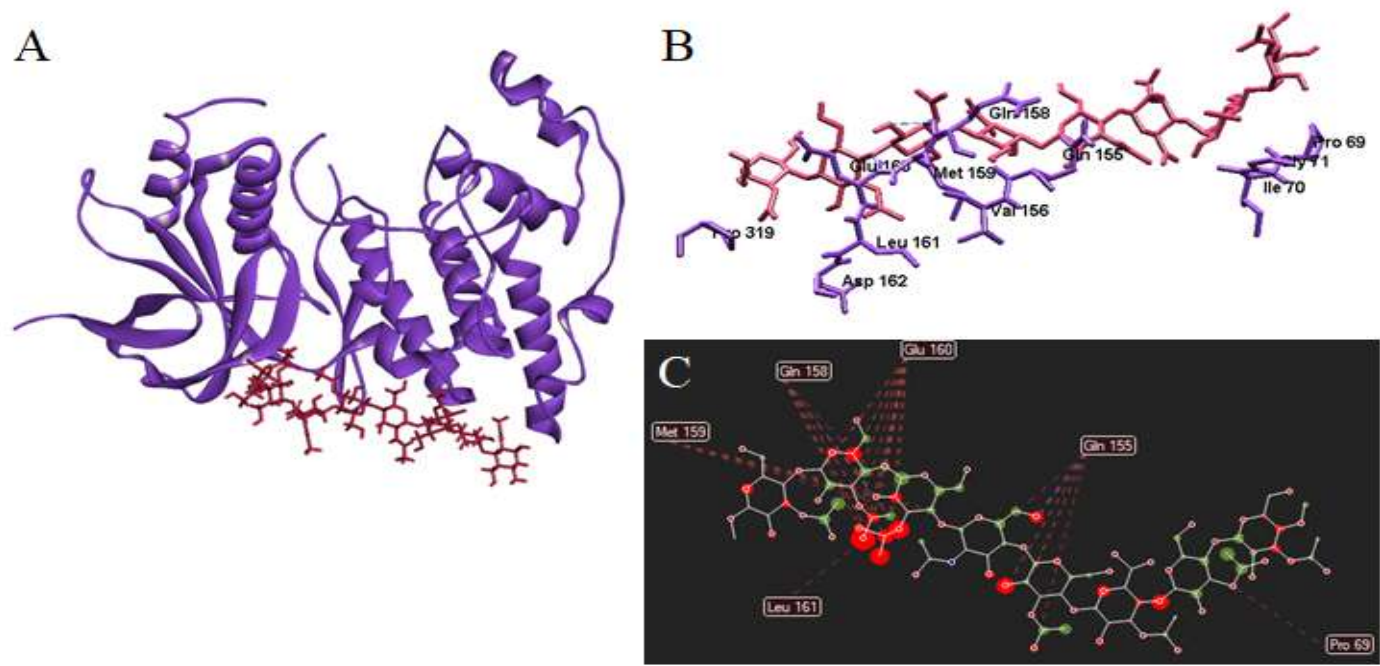

\section{Glukomanan - JNK}

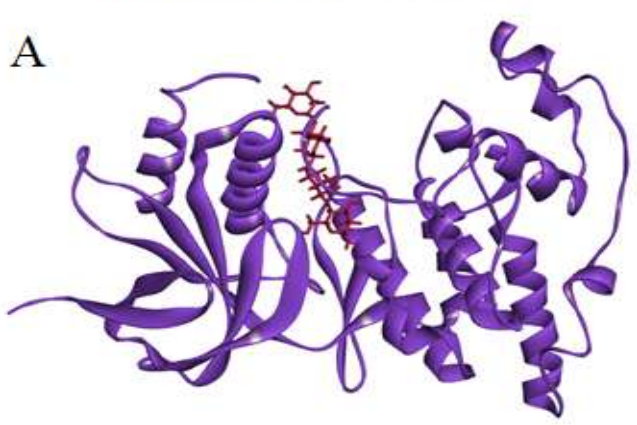

B
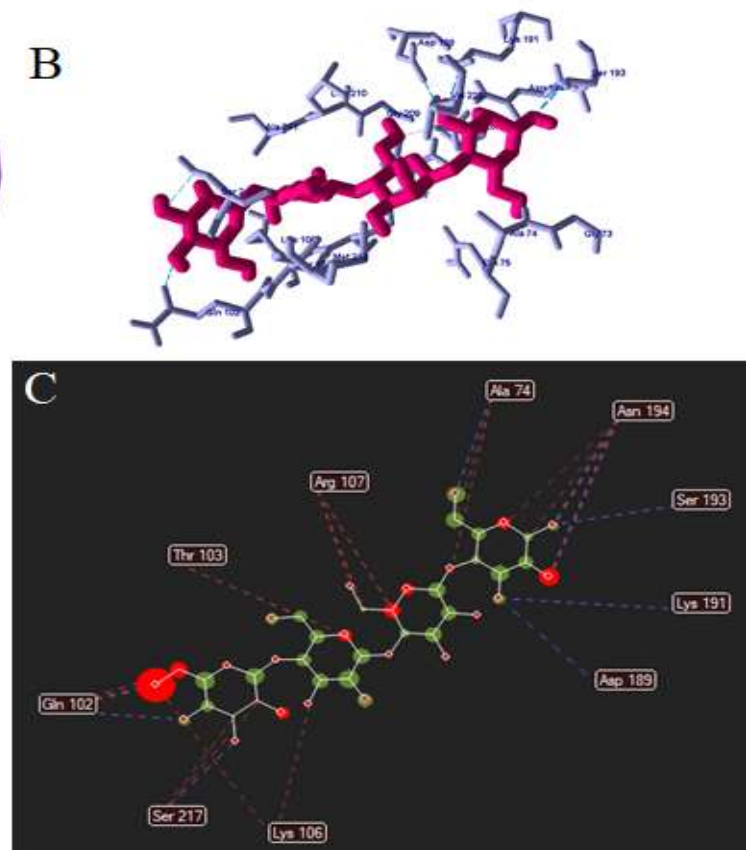

Gambar 1. Interaksi antara Glukomanan dan asemanan terhadap protein cJun NH2 terminal Kinase, A. Tampilan 3D kompleks ligand - protein, B. Tampilan sisi aktif residu JNK terhadap ikatan dengan ligand, C. Tampilan struktur 2D kompleks ligand - protein 
Inhibitor JNK lainnya juga ditunjukkan oleh antosianin beras hitam seperti cyanidin, peonidin, cyanidin -3-O-glukosida, dan peonidin -3-O-glukosida (Sari dkk., 2021). Keempat antosianin tersebut mampu menghambat aktivitas JNK dengan berinteraksi di daerah gatekeeper protein JNK (MET146) dan daerah fosforilasi JNK (Sari dkk., 2020). Adenosin tripospat (ATP) dilaporkan mengikat protein JNK pada residu MET149, CYS154, ASN152, GLY73, SER72, ILE70, dan MET146. Daerah ikatan senyawa non-ATP yaitu GLY199, VAL256, GLN253, PHE180, TYR230, ILE231, TRP234, dan TYR259 (Duong dkk., 2020). Aminopyrimidine telah dilaporkan juga mengeblok JNK pada daerah sekitar gatekeeper yaitu GLY35, LYS55, GLN37, MET108, MET111, dan ASN114. MET108 teridentifikasi sebagai daerah penutupan konformasi protein JNK dan merupakan daerah interaksi hidrofobik (Alam dkk., 2007). Energi ikatan yang dihasilkan asemanan - JNK yaitu $-596,6 \mathrm{~kJ} / \mathrm{mol}$ lebih rendah dari glukomanan - JNK, yakni 363,1 kJ/mol (Tabel 1).

Tabel 1. Interaksi antara Glukomanan dan asemanan terhadap protein cJun NH2 terminal Kinase

\begin{tabular}{|c|c|c|c|c|}
\hline Ligan - Protein & $\begin{array}{l}\text { Energi Ikatan } \\
(\mathrm{kJ} / \mathrm{mol})\end{array}$ & Residu JNK & Jenis Ikatan & Kategori \\
\hline \multirow{4}{*}{ Asemanan - JNK } & \multirow{4}{*}{-596.6} & A:LYS68:NZ $(5,5)$ & Elektrostatik & Attractive Charge \\
\hline & & $\begin{array}{l}\text { A:GLU160:HN }(1,7) ; \\
\text { A:GLN158:O }(1,8 ; 1,8 ; \\
1,9 ; 1,4) ; \text { A:GLN158:HN } \\
(2,6)\end{array}$ & $\begin{array}{l}\text { Ikatan } \\
\text { Hidrogen }\end{array}$ & Ikatan Hidrogen \\
\hline & & $\begin{array}{l}\text { A:GLU160:OE1 }(2,1 ; 3,0 ; \\
\text { 2,7); A:GLN155:OE1 } \\
(2,5) ; \text { A:PRO69:O }(2,6 ; \\
3,0)\end{array}$ & $\begin{array}{l}\text { Ikatan } \\
\text { Hidrogen }\end{array}$ & $\begin{array}{l}\text { Ikatan Hidrogen } \\
\text { Karbon }\end{array}$ \\
\hline & & $\begin{array}{l}\text { A:MET159 }(4,3) \\
\text { A:LEU161 }(4,5)\end{array}$ & Hidrofobik & Alkyl \\
\hline \multirow{4}{*}{ Glukomanan - JNK } & \multirow{4}{*}{-363.1} & $\begin{array}{l}\text { A:ALA74:HN }(1,7) ; \\
\text { A:SER217:OG }(2,6) ; \\
\text { A:ASN194:OD1 }(2,2) ; \\
\text { A:SER217:O }(2,7)\end{array}$ & $\begin{array}{l}\text { Ikatan } \\
\text { Hidrogen }\end{array}$ & Ikatan Hidrogen \\
\hline & & $\begin{array}{l}\text { A:ARG107:CD }(3,2) ; \\
\text { A:THR103:O }(2,5) ; \\
\text { A:SER217:N }(2,6 ; 2,1) ; \\
\text { A:SER217:OG }(1,9) ; \\
\text { A:GLN102:OE1 }(2,5)\end{array}$ & $\begin{array}{l}\text { Ikatan } \\
\text { Hidrogen }\end{array}$ & $\begin{array}{l}\text { Ikatan Hidrogen } \\
\text { Karbon }\end{array}$ \\
\hline & & $\begin{array}{l}\text { A:ASN194:OD1 }(2,1) ; \\
\text { A:ASN194:ND2 }(2,09) \\
\text { A:ASN194:HD22 }(1,2)\end{array}$ & Unfavorable & Unfavorable Bump \\
\hline & & A:LYS191:HZ2 $(1,4)$ & Unfavorable & $\begin{array}{l}\text { Unfavorable Donor- } \\
\text { Donor }\end{array}$ \\
\hline
\end{tabular}


Energi ikatan yang lebih rendah pada asemanan dimungkinkan karena adanya jenis ikatan yang bervariasi pada asemanan seperti elektrostatik, ikatan hidrogen, dan interaksi hidrofobik. Sedangkan glukomanan menunjukkan dua jenis ikatan yaitu ikatan hidrogen dan unfavorable. Penelitian sebelumnya melaporkan bahwa jenis interaksi dan jumlah interaksi berpengaruh terhadap energi ikatan ligand terhadap protein. Semakin banyak ikatan hidrogen dan interaksi hidrofob maka skor docking atau energi ikatan semakin rendah. Selain itu, interaksi elektrostatik, unfavorable dan gaya van der Waals berkontribusi terhadap pembentukan energi ikatan (Bare dkk., 2019; Bare dkk., 2019; Bare dkk., 2020; Bare dkk., 2020; Bare dkk., 2019; Bare dkk., 2019; Sari dkk., 2020; Sari dkk., 2020; Sari dkk., 2020).

\section{SIMPULAN}

Penelitian ini menyimpulkan bahwa asemanan dan glukomanan berikatan dengan protein JNK disisi aktif yang berbeda dan asemanan menunjukkan energi ikatan yang lebih rendah dari kompleks glukomanan - JNK. Asemanan dan glukomanan mampu berinteraksi dengan protein cJun NH2 terminal Kinase secara alosterik dan berpotensi dalam mencegah faktor resiko obesitas. Penelitian in vitro dan in vivo diperlukan untuk analisis antiobesitas lebih lanjut.

\section{UCAPAN TERIMAKASIH}

Penelitian ini didanai dan didukung oleh inijurnal.co. Terimakasih kepada tim inijurnal.co atas diskusi yang komprehesif.

\section{DAFTAR PUSTAKA}

Alam, M., Beevers, R. E., Ceska, T., Davenport, R. J., Dickson, K. M., Fortunato, M., ... Tait, L. J. (2007). Synthesis and SAR of aminopyrimidines as novel c-Jun N-terminal kinase (JNK) inhibitors. Bioorganic and Medicinal Chemistry Letters, 17(12), 3463-3467. https://doi.org/10.1016/j.bmcl.2007.03.078

Bakker, G. J., \& Nieuwdorp, M. (2014). Relationship Between Gut Microbiota , Energy Metabolism, and Obesity. The Microbiota in Gastrointestinal Pathophysiology. Elsevier Inc. https://doi.org/10.1016/B978-0-12-804024-9/00029-X

Bardwell, A. J., Frankson, E., \& Bardwell, L. (2009). Selectivity of docking sites in MAPK kinases. Journal of Biological Chemistry, 284(19), 13165-13173. 
https://doi.org/10.1074/jbc.M900080200

Bare, Yohanes;, Helvina, M., Elizabeth, A., \& Sari, D. R. T. (2019). Potensi Asam Kafeat Pada Kopi Sebagai Simultan Gen Peroxixme Proliferator-Activated Receptor Gamma (Ppar- $\gamma$ ): Studi in Silico. Saintek Lahan Kering, 2: JSLK Desember 2019), 52-53.

Bare, Yohanes, Maulidi, A., Sari, D. R. T., \& Tiring, S. S. N. D. (2019). Studi in Silico Prediksi Potensi 6-Gingerol sebagai inhibitor c-Jun N-terminal kinases (JNK). Jurnal Jejaring Matematika Dan Sains, 1(2), 59-63. https://doi.org/10.36873/jjms.v1i2.211

Bare, Yohanes, S, M., Putra, S. H. J., L, M. R. W. G., \& Sari, D. R. T. (2020). In-silico Approach for The Prediction of Chlorogenic Acid as PPAR- $\gamma$ Activator. Biota, 13(1). https://doi.org/10.20414/jb.v13i1.197

Bare, Yohanes, S, M., Tiring, S. S. N. D., Sari, D. R. T., \& Maulidi, A. (2020). Virtual Screening: Prediksi potensi 8-shogaol terhadap c-Jun N-Terminal Kinase (JNK). Jurnal Penelitian Dan Pengkajian Ilmu Pendidikan: E-Saintika, 4(1), 1. https://doi.org/10.36312/esaintika.v4i1.157

Bare, Yohanes, Sari, D. R., Rachmad, Y. T., Tiring, S. S. N. D., Rophi, A. H., \& Nugraha, F. A. D. (2019). Prediction Potential Chlorogenic Acid As Inhibitor Ace (In Silico Study). Bioscience, 3(2), 197. https://doi.org/10.24036/0201932105856-0-00

Bare, Yohanes, Sari, D. R. T., Rachmad, Y. T., Krisnamurti, G. C., \& Elizabeth, A. (2019). In Silico Insight the Prediction of Chlorogenic Acid in Coffee through Cyclooxygenase-2 (COX2) Interaction. Biogenesis: Jurnal Ilmiah Biologi, 7(2), 100-105. https://doi.org/10.24252/bio.v7i2.9847

Bitencourt-Ferreira, G., \& de Azevedo, W. F. (2019). Docking Screens for Drug Discovery. (G.

Bitencourt-Ferreira \& W. F. de Azevedo, Eds.), Methods in Molecular Biology (Vol. 2053). Ria Grande do Sul: Humana Press. https://doi.org/10.1007/978-1-4939-9752-7_12

Chang, H. C., Huang, C. N., Yeh, D. M., Wang, S. J., Peng, C. H., \& Wang, C. J. (2013). Oat Prevents Obesity and Abdominal Fat Distribution, and Improves Liver Function in Humans. Plant Foods for Human Nutrition, 68(1), 18-23. https://doi.org/10.1007/s11130-013-0336-2 Ciecierska, A., Drywień, M. E., Hamulka, J., \& Sadkowski, T. (2019). Nutraceutical functions of beta-glucans in human nutrition. Roczniki Panstwowego Zakladu Higieny, 70(4), 315-324. https://doi.org/10.32394/rpzh.2019.0082

Devaraj, R. D., Reddy, C. K., \& Xu, B. (2019). Health-promoting effects of konjac glucomannan 
and its practical applications: A critical review. International Journal of Biological Macromolecules, 126, 273-281. https://doi.org/10.1016/j.ijbiomac.2018.12.203

Duong, M. T. H., Lee, J. H., \& Ahn, H. C. (2020). C-Jun N-terminal kinase inhibitors: Structural insight into kinase-inhibitor complexes. Computational and Structural Biotechnology Journal, 18, 1440-1457. https://doi.org/10.1016/j.csbj.2020.06.013

González-castejón, M., \& Rodriguez-casado, A. (2011). Dietary phytochemicals and their potential effects on obesity: A review, 64, 438-455. https://doi.org/10.1016/j.phrs.2011.07.004

Hirata, T., Kobayashi, T., Wada, A., Ueda, T., Fujikawa, T., Miyashita, H., ... Nohara, T. (2011). Anti-obesity compounds in green leaves of Eucommia ulmoides. Bioorganic and Medicinal Chemistry Letters, 21(6), 1786-1791. https://doi.org/10.1016/j.bmcl.2011.01.060

Hossein Yazdi, M. (2019). Aloe Vera Extracted Polysaccharides Shift the Immune Responses of Tumor Bearing Mice Toward Th1 Pattern: Animal Study. Biomedical Journal of Scientific \& Technical Research, 16(4), 12148-12156. https://doi.org/10.26717/bjstr.2019.16.002873

Kragelj, J., Palencia, A., Nanao, M. H., Maurin, D., Bouvignies, G., Blackledge, M., \& Jensen, M. R. (2015). Structure and dynamics of the MKK7-JNK signaling complex. Proceedings of the National Academy of Sciences of the United States of America, 112(11), 3409-3414. https://doi.org/10.1073/pnas.1419528112

Makki, K., Froguel, P., \& Wolowczuk, I. (2013). Adipose Tissue in Obesity-Related Inflammation and Insulin Resistance : Cells , Cytokines , and Chemokines, 2013.

Mohamed, G. A., Ibrahim, S. R. M., Salah, R., \& Dine, E. (2014). Natural anti-obesity agents. Bulletin of Faculty of Pharmacy, Cairo University, 52(2), 269-284. https://doi.org/10.1016/j.bfopcu.2014.05.001

Mojiminiyi, O. A., Abdella, N. A., Al Arouj, M., \& Ben Nakhi, A. (2007). Adiponectin, insulin resistance and clinical expression of the metabolic syndrome in patients with Type 2 diabetes. International Journal of Obesity, 31(2), 213-220. https://doi.org/10.1038/sj.ijo.0803355

Nabavi, S. F., Russo, G. L., Daglia, M., \& Nabavi, S. M. (2015). Role of quercetin as an alternative for obesity treatment: You are what you eat! Food Chemistry, 179, 305-310. https://doi.org/10.1016/j.foodchem.2015.02.006

Patra, S., \& Nithya, S. (2015). Review of Medicinal Plants for Anti-Obesity Activity. Translational Biomedicine, 6(3), 1-22. https://doi.org/10.21767/2172-0479.100021 
Raipuria, M., Hardy, G. O., Bahari, H., \& Morris, M. J. (2015). Maternal obesity regulates gene expression in the hearts of offspring. Nutrition, Metabolism and Cardiovascular Diseases, 25(9), 881-888. https://doi.org/10.1016/j.numecd.2015.05.011

Sari, D. R.T., Safitri, A., Cairns, J. R. K., \& Fatchiyah, F. (2020). Virtual screening of black rice anthocyanins as antiobesity through inhibiting TLR4 and JNK pathway. Journal of Physics: Conference Series, 1665(1). https://doi.org/10.1088/1742-6596/1665/1/012024

Sari, D R T, Safitri, A., Cairns, J. R. K., \& Fatchiyah, F. (2020). Virtual screening of black rice anthocyanins as antiobesity through inhibiting TLR4 and JNK pathway. Journal of Physics: Conference Series PAPER, 1665, 1-7. https://doi.org/10.1088/1742-6596/1665/1/012024

Sari, Dewi Ratih Tirto;, Paemanee, A., Roytrakul, S., Cairns, J. R. K., Safitri, A., \& Fatchiyah, F. (2021). Black rice cultivar from Java Island of Indonesia revealed genomic, proteomic, and anthocyanin nutritional value. Acta Biochimica Polonica, 68(1), 55-63. https://doi.org/10.18388/abp.2020_5386

Sari, Dewi Ratih Tirto, Safitri, A., Cairns, J. R. K., \& Fatchiyah, F. (2020). Anti-Apoptotic Activity of Anthocyanins has Potential to inhibit Caspase-3 Signaling. Journal of Tropical Life Science, 10(1), 15-25. https://doi.org/10.11594/jtls.10.01.03

Xie, L., Su, H., Sun, C., Zheng, X., \& Chen, W. (2018). Recent advances in understanding the anti-obesity activity of anthocyanins and their biosynthesis in microorganisms. Trends in Food Science and Technology, 72(September 2017), 13-24. https://doi.org/10.1016/j.tifs.2017.12.002 